\title{
Four Arenas: Malaysia's 2018 Election, Reform, and Democratization
}

\author{
Kai Ostwald, University of British Columbia ${ }^{1}$ \\ Steven Oliver, Yale-National University of Singapore ${ }^{2}$
}

APSA Pre-Print 2019

\begin{abstract}
Malaysia's 2018 election saw the unexpected defeat of the United Malays National Organisation (UMNO) and the end of more than six decades of dominant party rule. Three core questions arise. How did the opposition finally overcome the extensive obstacles to achieve victory? What were anti-UMNO voters actually voting for? And finally, what do those answers imply for reform and democratization? We argue that Malaysia is actually comprised of four distinct identity-based polities, each with a unique electoral dynamic and vision for the country's political future. Using this four arenas framework provides key insights into UMNO's defeat, which was achieved by making inroadslargely through elite splits - in two previously impenetrable arenas. As one arena remains electorally pivotal, it exerts a disproportionately large influence on the new government's reform agenda, as well as ensures the continued salience of identity politics.
\end{abstract}

Keywords: Malaysia; Election; Ethnic Politics; Identity; Democratization; UMNO; Pakatan Harapan; Reform

\footnotetext{
${ }^{1}$ Kai Ostwald is an Assistant Professor in the School of Public Policy \& Global Affairs and the Department of Political Science at the University of British Columbia. kai.ostwald@ubc.ca ${ }^{2}$ Steven Oliver is an Assistant Professor of Political Science at Yale-National University of Singapore. steven.oliver@yale-nus.edu.sg
} 


\section{Introduction}

Malaysia's 2018 election saw the unanticipated defeat of the United Malays National Organisation (UMNO) and its Barisan Nasional (BN) coalition partners, which ended more than six decades of dominant party rule. ${ }^{3}$ The regime demonstrated remarkable resilience prior to 2018, surviving the third-wave of democratisation relatively unscathed, weathering the turbulence of the Asian financial crisis, and overcoming numerous internal crises. And yet, as results rolled in on the night of 9 May 2018, it became clear that Malaysia would soon transition to its first post-UMNO government since independence in 1957.

Three questions stand out in the wake of the transition. First, how did the opposition finally defeat UMNO despite a heavily biased electoral process and numerous structural obstacles? In other words, what makes the country's 14th general election (GE14) different from previous ones? Second, while it is clear that Malaysians overwhelmingly voted against UMNO in GE14, it is less clear what alternative they were voting for, since not all opposition voters shared the same vision of a post-UMNO "New Malaysia" (Malaysia Baru). In short, what were voters voting for? Third, what do the answers to these questions imply for reform and democratization in post-transition Malaysia?

We hold that carefully examining the interplay between geography and identity provides important insights into these questions. Specifically, we argue that Malaysia is comprised of four distinct, identity-based polities, each with their own electoral dynamics and visions of an ideal post-transition Malaysia. By explicitly disaggregating analyses into these polities - which we refer to as electoral arenas - we are able to present coherent insights into Malaysia's transition and post-transition politics.

Disaggregating an electorate to facilitate analysis of political behavior is not novel. To the contrary, nearly all political analyses rely on some form of disaggregation. Typically, studies default to familiar categories like major administrative units or ethnic groups. In the Malaysian context, these are the states and the essentialized Malay, Chinese, Indian, Other groups. Yet these default categories are poorly-suited for understanding political behavior

\footnotetext{
${ }^{3}$ The coalition was known as the Alliance prior to 1973.
} 
due to considerable within-group variation and across-group consistency. ${ }^{4}$ By providing more coherent categories, the four arenas framework allows for clearer insights into Malaysia's unprecedented transition and its aftermath. Specifically, the framework allows for four broader contributions.

First, it clarifies how PH achieved victory in GE14 despite the numerous structural obstacles. Election results are highly consistent in two of the four arenas over the last three elections. The defeat of UMNO in GE14, in short, occurred due to unprecedented seat gains in the remaining two arenas. Most of those gains were achieved by $\mathrm{BN}$ splinter parties, making elite splits and PH's "soft incorporation" of BN politics a decisive element of the electoral breakthrough. To be clear, the seat gains came on top of a well-established base, but they were the decisive factor that allowed PH to achieve in GE14 what its predecessors could not.

Second, there is a high degree of coherence to the factors motivating voting behavior within the individual arenas. As such, the four arenas framework provides clarity on what voters were voting for, and consequently, how Malaysia's transition speaks to theories of democratization. Modernization theory strongly explains voting behavior in one arena, but subtly different forms of identity politics and patronage politics dominate in the others. This variation in voting behaviors across the arenas means that no single, overarching explanation for the watershed transition is possible.

Third, isolating the decisive arenas and clarifying the political dynamic prevalent in them is instructive for understanding the nature of post-transition Malaysian politics. Identity plays a central role. Most votes against the BN in the electorally decisive arenas were not votes for the Reformasi-inspired vision of a (relatively) post-racial Malaysia that has become associated with the Malaysia Baharu (New Malaysia). Specifically, while the generally progressive arena that Pakatan has dominated in the last two elections supports a leveling of

\footnotetext{
${ }^{4}$ For example, we would expect different voting behavior from a middle-class Kuala Lumpur-based Malay, a rural Johor-based Malay, and a suburban Kelantan-based Malay. This within-group variation reduced the utility of the broader Malay category for understanding voting behavior. Simultaneously, there is little need to distinguish between Kelantan and Terengganu, since voting behavior is similar enough across the two states that the distinction only adds complexity without providing additional insight.
} 
Malaysia's de facto racial hierarchy, the electorally decisive arenas do not endorse deep social transformation of that kind. With the voters from those decisive arenas key to maintaining power, $\mathrm{PH}$ has largely defaulted to their preferences on identity-related issues. Further entrenching this cautious approach is the rapidly consolidating partnership between UMNO and the Parti Islam se-Malaysia (PAS), which has seized upon those status loss anxieties in a bid to destabilize PH and pull pivotal voters back to themselves. Consequently, $\mathrm{PH}$ finds reform on identity-related issues too risky to press forward, leaving large tracts of the Reformasi-inspired reform agenda unfulfilled and the post-racial New Malaysia sought by its progressive core ever-elusive.

Finally, the Malaysian case provides a clear illustration of what is intuitively understood but seldom articulated explicitly in other contexts: the electorate in diverse societies is often deeply divided along lines that only partially map on to the default identity or administrative categories. In the United States, for example, "red" and "blue" areas display remarkable voting consistency, but are often not ethnically homogenous or geographically contiguous, particularly after urbanization and relocation patterns of the last half century.

\section{Malaysian Politics and the Breakdown of Dominant Party Rule}

The history of Malaysian politics is the history of UMNO and its coalition partners, which dominated the political sphere from independence in 1957 through the surprise transition in 2018. So enduring was UMNO's rule, that Malaysia was often described as a quintessential dominant party system or some related variant (Gomez 2016; Brownlee 2007; Slater 2012; Wong, Chin, and Othman 2010). UMNO itself was founded in 1946 as a vehicle to represent the interests of ethnic Malays and agitate against the British-endorsed Malayan Union, which was seen as making too many concessions to the country's large ethnic Chinese and Indian minorities. After successfully blocking the Union, UMNO ushered in Malaya's independence together with its junior coalition partners the Malaysian Chinese Association (MCA) and the Malaysian Indian Congress (MIC). The new federation expanded in 1963 to include the Bornean territories of Sabah and Sarawak as well as Singapore. ${ }^{5}$

\footnotetext{
${ }^{5}$ The Federation of Malaya took the name Federation of Malaysia with the cession of Sabah, Sarawak, and Singapore in 1963. Singapore left the federation in 1965, leaving the current 13 state arrangement.
} 


\section{Origins of UMNO's Enduring Dominance}

UMNO and its coalition partners won every general election from 1957 until 2018, leading to an uninterrupted 61 years in power. For large stretches of that period, the coalition held a two-thirds parliamentary supermajority that allowed it to amend the constitution at will. Its resilience resulted from numerous factors. Malaysia's strong developmental record conferred a degree of performance legitimacy (Pepinsky 2007). The monetization of politics and resource asymmetries fundamentally advantaged the incumbent coalition (Gomez 2016; 2012). Interference in opposition politics encumbered opposition coordination (Gandhi and Ong 2019). Extensive manipulations of the electoral process also provided UMNO with fundamental advantages at the ballot box (Ostwald 2017a). As Croissant and Lorenz (2018, 154) noted just prior to GE14, "[w]hile elections are [typically] designed to make governments, in the Malaysian context, elections are not intended to break them."

The enduring presence of identity politics also played an important role in UMNO's resilience. In addition to Malaysia's ethnic majority Malay group, the country has significant Chinese and Indian communities whose roots largely trace back to economic migration initiated by the Colonial British in the nineteenth and early twentieth centuries. ${ }^{6}$ Malays and a small number of aboriginal groups - which are concentrated in East Malaysia - are recognized as indigenous and frequently referred to as Bumiputera. The 1957 Constitution grants the Bumiputera a "Special Position" in the country, and makes Malay its official language and Islam official religion. ${ }^{7}$ Moreover, Article 153 articulates mechanisms to safeguard this special position, including quotas in the civil service, education, and licencing.

Lingering tensions between the ethnic groups, fueled by the enduring economic weakness of the Malays, culminated in serious ethnic violence in 1969. Agitation by a faction within UMNO, which accused the party's leadership of making too many concessions to the Chinese and Indians, set the stage for the 1971 New Economic Policy (NEP), the goal of

\footnotetext{
${ }^{6}$ At present, Malays constitute approximately $50 \%$ of the population. The two largest minority groups (i.e. Chinese, 22\%; Indians. 7\%) are concentrated in the Peninsula. The remainder of the population is comprised of non-Malay indigenous groups found primarily in East Malaysia, as well as several other small groups.

${ }^{7}$ As per the Constitution, Islam is the religion of all Malays and apostacy is forbidden.
} 
which was nothing less than the re-engineering of Malaysia's social structure through extensive positive discrimination measures that advantaged the Malays and other Bumiputera. Few areas of the economy or society were beyond its reach. In practice, it substantiated and significantly reinforced the tiered citizenship implied by Article 153 of the Constitution, underscoring the special position of the Malays at the top of that hierarchy (Chin 2009). ${ }^{8}$ While the NEP formally expired in 1991, it was replaced by development plans that carried forward its essence (Gomez and Saravanamuttu 2012).

Over the decades a simplified and somewhat revisionist narrative on the relationship between Malaysia's ethnic groups has taken root. It maintains that independence was achieved through a social contract — often referred to as the "Bargain"- under which the migrant Chinese and Indian communities were granted citizenship in exchange for the Malays receiving a guarantee of political power (Puthucheary 2008). The narrative occasionally takes on particularly virulent forms, where the pro-Malay protectionist measures become an endorsement of Ketuanan Melayu (Malay supremacy) over Tanah Melayu (Malay soil); the Chinese and Indian communities, by contrast, are cast as pendatang (recent immigrants), and thus guests rather than legitimate co-inhabitors of the country. Within this paradigm, the racial hierarchy is especially pronounced. ${ }^{9}$

\section{The Breakdown of Dominant Party Rule}

In retrospect, UMNO's defeat and the end of dominant party rule are rooted in the Reformasi movement of the late 1990s (Wong and Ooi 2018; Weiss 2006; Noor 1999). This movement articulated a range of progressive social and institutional reforms, and saw the eventual

\footnotetext{
${ }^{8}$ Horowitz (1985) distinguishes between ranked and unranked ethnic structures with reference to coincidence of social class and ethnic groups. Using this scheme, Malaysia's major ethnic groups are classified as unranked. We use 'ranked' to denote an informal tiered citizenship, where a particular group - the Malays and other Bumiputera in the case of Malaysia - enjoy a range of legally recognized privileges and advantages unavailable to other groups.

${ }^{9}$ While these positions are most often associated with Malay supremacy groups like Perkasa or ISMA, they are also explicitly maintained by some state-affiliated actors as well. For example, one year after the election the Perlis mufti stated "A nation must have its identity... China is for Chinese. The Indian continent is for Indians, but Tanah Melayu is not for Malays? Cannot, cannot... There must be a dominant race." See the Malay Mail story from 16 August 2019 entitled "Perlis mufti says justice for all, but insists Tanah Melayu for Malays as "dominant race"”.
} 
creation of a series of viable opposition coalitions built around two progressive and nominally multiethnic parties: the predominantly Malay Parti Keadilan Rakyat (PKR) and predominantly Chinese Democratic Action Party (DAP). Together with PAS, this coalition managed an unprecedented breakthrough in the 2008 general election, denying the $\mathrm{BN}$ the popular vote in the peninsula as well as its customary supermajority in parliament, and forcing it to concede control of five states. A highly coordinated and energized PR opposition made further inroads during GE13, where the BN lost the popular vote by four percent. Extensive malapportionment, however, provided the BN a twenty percent parliamentary seat advantage and kept a transition well at bay (Wong 2018; Ostwald 2013). This defeat, despite strong opposition coordination and the remarkable popular vote victory made a transition appear nearly impossible through the ballot box. In the shadow of this deflating realization, familiar tensions between PAS and the DAP resurfaced, eventually leading to the coalition's fragmentation.

Several unexpected developments fundamentally altered elite politics in the run-up to GE14. Most important was the growing discontent against Najib, whose involvement in the 1MDB scandal (Case 2017) compounded allegations of poor performance. Najib resorted to increasingly authoritarian tactics to ward off challenges to his leadership from within UMNO, including the purge of his deputy prime minister Muhyiddin Yassin and Mahathir's son Mukhriz Mahathir (Nadzri 2018). Those cavalier maneuvers insulated Najib from intraparty attacks, but also focused dissent against him, eventually leading Mahathir himself to leave UMNO and form the UMNO-clone opposition party known as Parti Pribumi Bersatu Malaysia (Bersatu). Like UMNO, Bersatu limited its membership to Malays (and other Bumiputera) and maintained the objective of upholding the special position of Islam and the Malays. The new party quickly drew in other UMNO defectors. Despite this, Bersatu joined PKR, the DAP, and PAS-splinter party Amanah, to form the Pakatan Harapan (PH) opposition coalition. A de facto partnership with Sabah-based BN-splinter party Parti Warisan Sabah (Warisan) expanded PH's potential reach into East Malaysia. While PKR's Anwar Ibrahim was nominally recognized as PH's leader, 92-year-old Mahathir became Chairman and Prime Minister Designate. Nonetheless, few gave PH a realistic chance of victory in GE14, with many assuming the coalition of convenience would be short-lived. 


\section{An Unexpected Transition}

The election returns from 9 May 2018 shocked nearly all. Together with Warisan, PH captured $49 \%$ of the popular vote and 121 of the 222 lower house seats, well above the 112seat threshold required to form a government. The BN managed just 79 seats on an anemic vote share of $34 \%$. PAS, which contested widely as a third party, secured 18 seats. ${ }^{10}$ The outcome was decisive enough to take the BN's major obstructionist options off the table, thus forcing Najib to concede defeat. Nearly 24 tense hours after most polls closed, Mahathir was sworn in as Malaysia's seventh Prime Minister by the Yang di-Pertuan Agong, formally ending over half a century of uninterrupted UMNO rule.

How do we explain this unanticipated outcome? Several accounts highlight the role of elite defections, particularly of former UMNO prime minister Mahathir Mohamad, whose ability to attract votes from the country's ethnic Malay majority and to overcome interference by UMNO-aligned institutions was seen as vital (Abdullah 2019; Lemiere 2018; Hutchinson 2018). Structural changes and modernization likewise feature among the explanations (Slater 2018), as do the effects of economic conditions (Hutchinson 2018), civil society activism (Chan 2018), legitimacy loss due to monetization of consent (Saravanamuttu and Mohamad 2019), and the increasing effectiveness of PH's own personalistic politics (Dettman and Weiss 2019). One major edited volume (Gomez and Mohamad Osman 2019) focuses on divisions among the country's ethnic Malay majority, while another (Lemiere 2019) instead looks towards the country's ethnic minorities for insights.

Explanations, in other words, are varied and focus overwhelmingly on particular dimensions of the election. The results themselves indicate considerable diversity in voting behavior along ethnic and geographic lines. Credible polls from the Merdeka Centre, for example, suggest that $\mathrm{PH}$ captured $95 \%$ of the Chinese and $70-75 \%$ of the Indian vote, but only a meagre $25-30 \%$ of the Malay vote (Hutchinson 2018). Moreover, PH did not win a single seat in PAS's traditional heartland, and PAS, by contrast, was almost entirely shut out of seats beyond that heartland. We argue that a parsimonious and overarching explanation

\footnotetext{
${ }^{10}$ A set of counterfactual simulations in Ostwald, Schuler, and Chong (2018) suggest that the threecornered fights had relatively little effect on the election outcome due to the territorial concentration of supporters.
} 
for GE14 requires careful consideration of that ethnic and geographic variation, which we provide through the Four Arenas framework below.

\section{Four Arenas of Malaysian Politics}

We conceive of Malaysia as comprised of four distinct polities, each with its own unique electoral dynamics. We call these polities electoral arenas. The four arenas are based on Malaysia's 222 electoral districts and coded using the criteria described below. We argue that understanding Malaysian politics in this disaggregated way offers clear insights into GE14, as well as into the country's ongoing political development.

We call the first arena Northeast, which comprises all districts in the northeastern states of Kelantan and Terengganu. The second is called East Malaysia, which comprises all districts of Sabah and Sarawak. The third is called Peninsular Diverse, which we define as peninsular districts that had greater than 50\% non-Malays in GE14. ${ }^{11}$ Most, though not all of these, are urban or semi-urban in nature. ${ }^{12}$ The final is called Peninsular Malay, which we define as a peninsular district outside of Kelantan and Terengganu that is greater than $50 \%$ Malay. Figure 1 shows the geographic distribution of the four arenas within Malaysia.

\footnotetext{
${ }^{11}$ We use a $50 \%$ threshold for its simplicity, not because we suggest that it is a hard line after which a district's political dynamic suddenly changes. We repeat the categorization using $60 \%$ non-Malay and $67 \%$ non-Malay thresholds. While a small number of districts are categorized differently, the general conclusions remain unchanged. As such, we show only the $50 \%$ threshold.

${ }^{12}$ While the arenas contain aspects of the urban/rural divide that has attracted attention, it ultimately remains distinct. For a discussion of that framework, see Pepinsky (2015) and Ng et al (2015).
} 


\section{Figure 1: Geographic Distribution of Malaysia's Four Electoral Arenas}

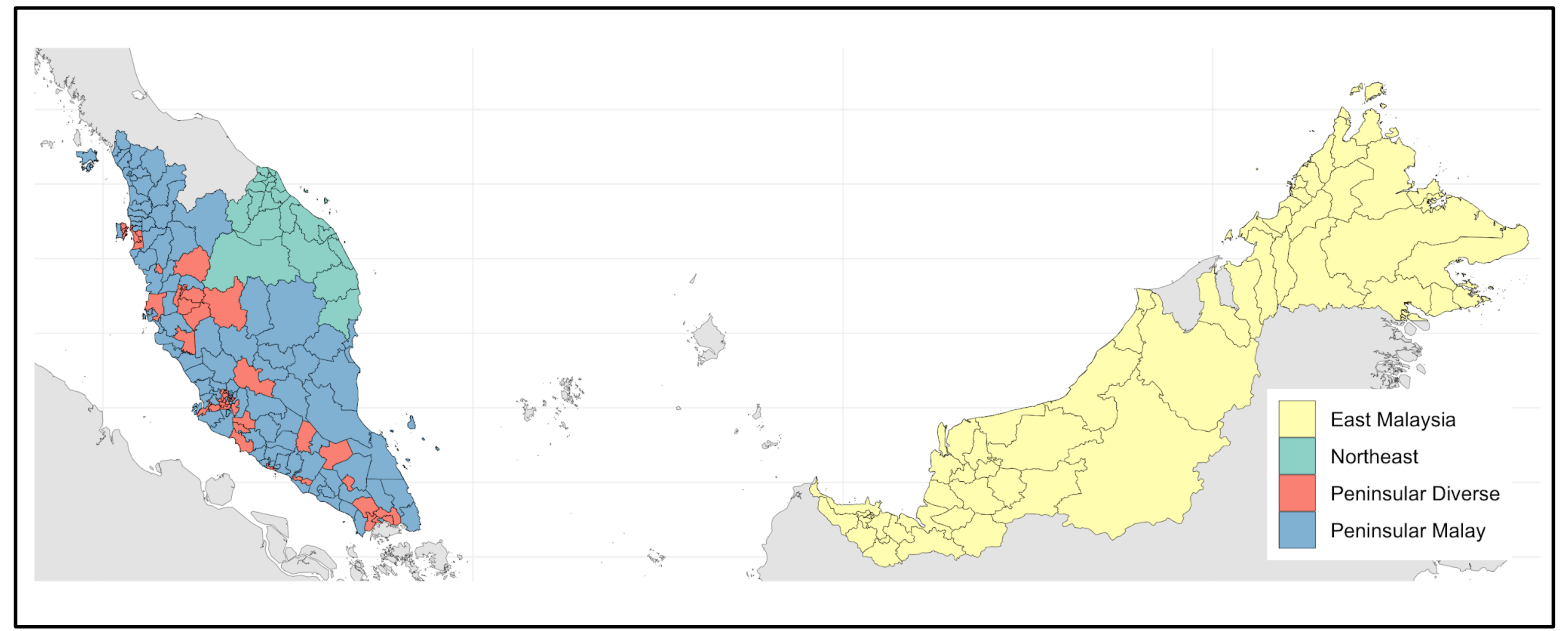

Sources: Data from Tindak Malaysia and STAR Online

Note: Data on electoral district boundaries is from Tindak Malaysia. Data on ethnic composition of districts used to distinguish between Peninsular Diverse and Peninsular Malay arenas is from STAR Online.

The four arenas have clear historic origins grounded in the period of Malaysia's state formation. The Peninsular Diverse arena has its roots in the British Straits Settlements, which comprised the coastal areas of Penang, Malacca, and Singapore. As entrepot economies connected to global trade routes running through the Strait of Malacca, they were diverse and outward oriented, remaining largely insulated from the traditional, Sultancontrolled politics of the broader peninsula that are the origins of the Peninsular Malay arena. An unrelenting hunger for raw materials found in that arena catalyzed British expansion beyond the coastal enclaves, eventually leading to the establishment of the Federated Malay States in 1895. The nature of resource exploitation in the new areas of British influence led to several waves of migrant labor from China and India that transformed the demographics of the western half of the peninsula, merging elements of traditional and colonial structure.

By contrast, British control over the Unfederated States was less direct, especially in the north: the states of Kelantan, Terengganu, Kedah, and Perlis did not come under British control until their transfer from Thailand under the Bangkok Treaty of 1909. Consequently, they did not experience the same economic and demographic transformation as the rest of the peninsula. From the 1950s onwards, PAS has effectively leveraged the resulting clear 
demographic and social differences relative to the rest of the peninsula, which has helped to sustain the unique features of the region, particularly in the northeastern states of Kelantan and Terengganu (Kessler 1978). The latter two remain distinct enough to comprise the Northeast arena.

In what is now East Malaysia, the British North Borneo Company governed Sabah, while the White Rajah dynasty governed Sarawak until Japanese occupation in 1941. As Chin $(2014,83)$ writes, "[i]n terms of history, culture and demography, there was nothing in common between the peoples of the Malayan peninsula and Borneo, other than that all were once part of the British Empire." Indeed, Sabah and Sarawak operated more or less independently from British Malaya throughout the colonial period, and retain a distinct — and relatively insulated-political dynamic through today that produces occasional calls for secession from the federation.

The four arenas are ideal types. This means some individual districts have elements that we associate with multiple arenas. ${ }^{13}$ Moreover, even arenas that closely approximate the ideal type are comprised of heterogeneous voters, so not every voter will accord with the descriptions we attach to their arena. Malaysia's Westminster-style first-past-the-post electoral system, however, amplifies a given district's majority preferences, allowing those to overshadow others. Table 1 provides basic descriptive statistics for these arenas.

Table 1: Descriptive Statistics of Malaysia's four Electoral Arenas

\begin{tabular}{lrrrr}
\hline Electoral Arena & $\begin{array}{r}\text { Electoral } \\
\text { Seats }\end{array}$ & $\begin{array}{r}\text { Voters } \\
\text { (Million) }\end{array}$ & $\begin{array}{r}\text { Voters per } \\
\text { Seat } \\
\text { (Thousand) }\end{array}$ & $\begin{array}{r}\text { Percent } \\
\text { bumiputera } \\
(\%)\end{array}$ \\
\hline Peninsular Diverse & 48 & 4.4 & 91.9 & 33.9 \\
Northeast & 22 & 1.8 & 81.2 & 96.0 \\
Peninsular Malay & 95 & 6.4 & 67.1 & 71.8 \\
East Malaysia & 57 & 2.4 & 41.5 & 76.1 \\
\hline
\end{tabular}

\footnotetext{
${ }^{13}$ For example, the dynamic we associate with the Northeast arena is present in some parts of Kedah and Perlis, while the Peninsular diverse dynamic describes political behavior in some urban and semi-urban areas of East Malaysia. Nevertheless, the categorization presented here helps to orient thinking about important differences.
} 
Sources: Data from SPR and Star Online

Note: Reported figures based upon authors' calculations. Data on seats and voters is from SPR. Data on ethnic composition is from STAR Online. Percent Bumiputera is calculated based upon ethnic composition and the number of voters in each arena.

Two observations warrant brief discussion. First, the Peninsular Diverse and Peninsular Malay arenas contain most of Malaysia's electorate. Neither arena, however, has a majority of seats, in practice requiring a strong performance in more than one arena to cross the 112 seat threshold needed for government formation. Second, variation in the number of voters per seat between arenas indicates significant malapportionment that over-weights votes in East Malaysia and Peninsular Malay, essentially inflating their political influence relative to their number of voters. Indeed, votes in those arenas count for between one-and-a-half and two times as much as do votes in the Peninsular Diverse and Northeast arenas. ${ }^{14}$

Figure 2 illustrates the electoral performance-measured by the percentage of seats won-in each electoral arena by the dominant coalitions in GE13 and GE14. To facilitate comparison of results across the two elections, we consider PAS separately from PR in GE13. Red denotes the PH/PR coalitions (with PAS considered separately from PR in GE13); green denotes PAS; and blue denotes the BN.

\footnotetext{
${ }^{14}$ Oliver and Ostwald (2018) show that pro-BN partisan bias resulting from malapportionment provided $\mathrm{UMNO}$ and the BN with an even greater potential parliamentary seat advantage over PH in GE14 relative to GE13. Although UMNO failed to capitalize on this advantage in GE14 due to the collapse in its popular support relative to GE13, the prevailing electoral map leaves open the opportunity for a resurgent UMNO to capitalize on this in the next election.
} 
Figure 2: Coalition Seat Shares across Malaysia's four arenas

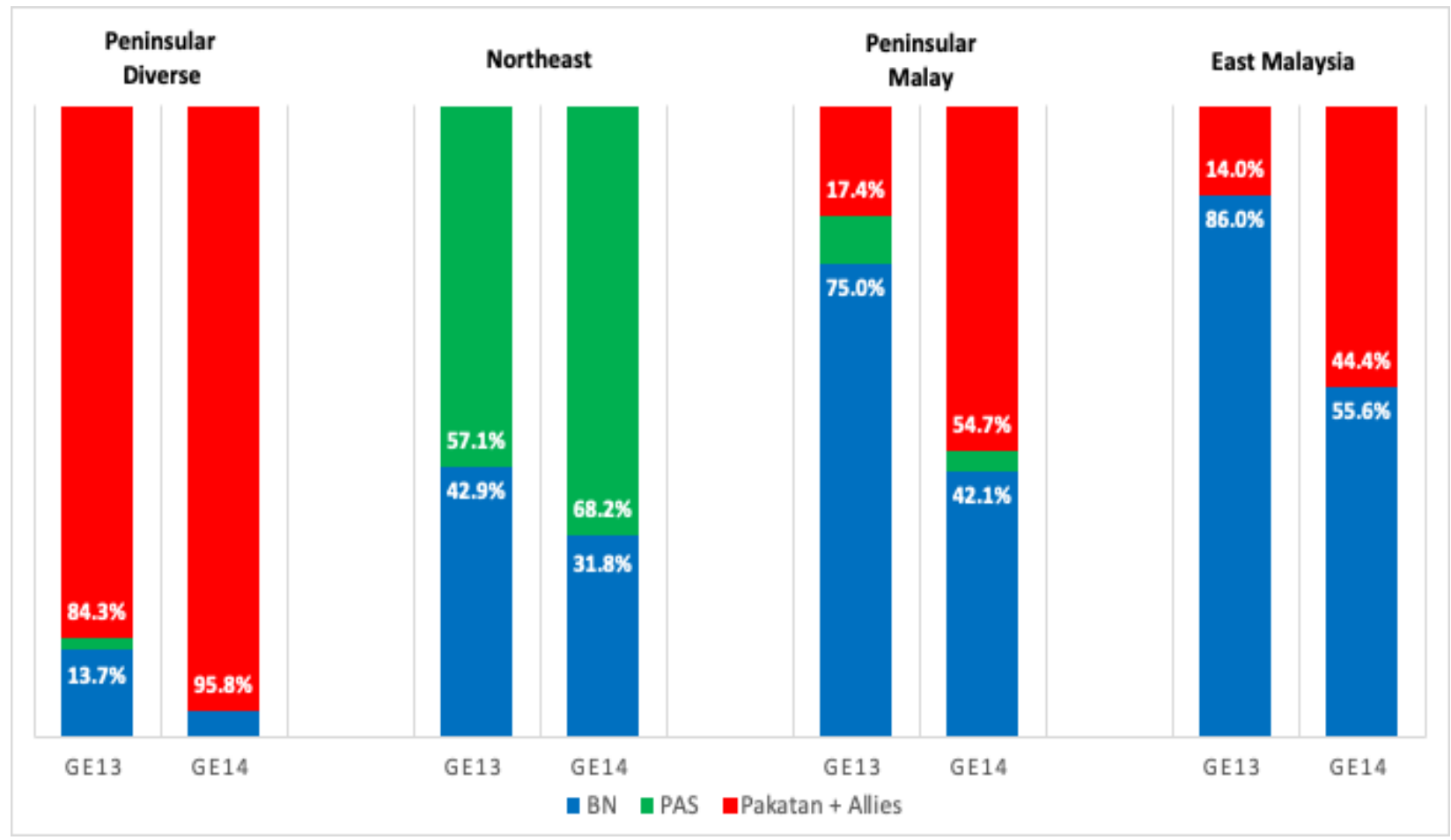

Sources: Data from SPR

Note: Reported figures based upon authors' calculations.

Comparing GE13 and GE14, there is clearly little change in the Peninsular Diverse and Northeast arenas. In the former, Pakatan (minus PAS) thoroughly dominated both elections, winning nearly every seat it contested. In the latter, PAS and UMNO split the available seats at roughly similar proportions, with other Pakatan parties-including PAS-splinter Amanah - proving to be totally uncompetitive.

By contrast, there is a dramatic shift in results across the two elections in the Peninsular Malay and East Malaysia arenas. In the Peninsular Malay arena, the BN dominated GE13 by capturing 75\% of seats, while PR (minus PAS) managed to win only $17 \%$ of seats. GE14 was far more symmetric: the BN won $42.1 \%$ of seats against $54.7 \%$ for PH. Although PAS contested $94.7 \%$ of seats within this arena in GE14, it was a non-factor and won a mere three seats in Kedah. In the East Malaysia arena, the BN dominated GE13 by winning $86 \%$ of seats while PR (again, minus PAS) managed to win only $14 \%$ of seats within the arena. This shifted to near parity in GE14 with the BN winning 55\% of seats 
against $45 \%$ for PH (with Warisan). Again, PAS was a non-factor, as it failed to win a single seat in East Malaysia.

Table 2 provides more granular detail on coalition performance in the two elections. As before, PAS is considered separately from PR in GE13. The column titled Percent Deposit Loss captures the percentage of seats in which a given coalition/party failed to cross the $12.5 \%$ vote threshold required to recoup the election deposit; this indicates the relative non-competitiveness of a party and its platform.

Table 2: Coalition Electoral performance across Malaysia's four arenas

GE13

\begin{tabular}{|c|c|c|c|c|c|c|c|c|c|}
\hline $\begin{array}{l}\text { Electoral } \\
\text { Arena }\end{array}$ & $\begin{array}{r}\text { Vote } \\
\text { Share }\end{array}$ & $\begin{array}{r}\text { Seats } \\
\text { Contested }\end{array}$ & $\begin{array}{l}\text { Seats } \\
\text { Won }\end{array}$ & $\begin{array}{r}\text { Wins } \\
(\%)\end{array}$ & $\begin{array}{r}\text { Vote } \\
\text { Share }\end{array}$ & $\begin{array}{r}\text { Seats } \\
\text { Contested }\end{array}$ & $\begin{array}{l}\text { Seats } \\
\text { Won }\end{array}$ & $\begin{array}{r}\text { Wins } \\
(\%)\end{array}$ & $\begin{array}{r}\text { Percent } \\
\text { Deposit } \\
\text { Loss }\end{array}$ \\
\hline \multicolumn{10}{|l|}{$\begin{array}{l}\text { Peninsular } \\
\text { Diverse }\end{array}$} \\
\hline $\mathrm{BN}$ & 34.8 & 51 & 7 & 13.7 & 21.3 & 48 & 2 & 4.2 & 12.5 \\
\hline $\mathrm{PR} / \mathrm{PH}$ & 62.4 & 50 & 43 & 86.0 & 70.8 & 48 & 46 & 95.8 & 2.1 \\
\hline PAS & 1.8 & 1 & 1 & 100.0 & 7.6 & 33 & 0 & 0.0 & 72.7 \\
\hline
\end{tabular}

Northeast

\begin{tabular}{rrrrrrrrrr}
\hline BN & 48.7 & 21 & 9 & 42.9 & 39.0 & 22 & 7 & 31.8 & 0.0 \\
PR/PH & 8.4 & 4 & 0 & 0.0 & 11.0 & 22 & 0 & 0.0 & 63.6 \\
PAS & 45.5 & 18 & 12 & 45.5 & 48.0 & 22 & 15 & 68.2 & 0.0 \\
$\begin{array}{r}\text { Peninsular } \\
\text { Malay }\end{array}$ & & & & & & & & & \\
\hline BN & 53.2 & 92 & 69 & 75.0 & 37.7 & 95 & 40 & 42.1 & 0.0 \\
PR/PH & 26.2 & 46 & 16 & 34.8 & 44.5 & 95 & 52 & 54.7 & 1.1 \\
PAS & 20.0 & 45 & 7 & 15.6 & 20.3 & 90 & 3 & 3.3 & 23.3
\end{tabular}


East

Malaysia

\begin{tabular}{rrrrrrrrrr}
\hline BN & 57.1 & 57 & 49 & 86.0 & 40.0 & 57 & 30 & 40.0 & 0.0 \\
PR/PH & 34.6 & 50 & 8 & 16.0 & 45.0 & 56 & 24 & 45.0 & 5.4 \\
PAS & 1.9 & 7 & 0 & 0.0 & 1.0 & 14 & 0 & 0.0 & 92.9 \\
\hline
\end{tabular}

Sources: Data from SPR

Note: Reported figures based upon authors' calculations.

\section{Explaining the result}

These outcomes suggest a parsimonious, overarching answer to the question of how $\mathrm{PH}$ defeated the BN in GE14. Returning to GE13, PR dominated the Peninsular Diverse arena and captured a majority of seats in the Northeast. While this was sufficient to win the popular vote, it left PR significantly short of the 112-seat threshold to form a government. Crossing that threshold in GE14 would require Pakatan to swing an additional 25 seats from the BN, far more than remained available in the Peninsular Diverse and the Northeast arenas. Without PAS in the coalition, the seat requirement increased to 40 . Defeating the $\mathrm{BN}$, in other words, required making significant inroads into the BN-stronghold Peninsular Malay and East Malaysian arenas.

There was little to indicate that this was feasible. The PKR and DAP's Reformasiinspired platform resonated in the urbanized Peninsular Diverse arena, but its calls for protection of civil liberties, space for political pluralism, and a shift away from structuring politics around rigidly-defined racial and religious categories had limited appeal beyond it. ${ }^{15}$ In East Malaysia, Pakatan had already won the few relatively urbanized seats, and had no way of competing against the entrenched patron-client ties outside them. In other words, the $\mathrm{BN}$ appeared to have an impenetrable stranglehold on the pivotal and over-weighted arenas that held the key electoral success.

\footnotetext{
${ }^{15}$ Some aspects of the progressive narrative may reflect more what Thompson (2013) calls an "urban cosmopolitan chauvinism" than broadly supported sentiments.
} 
This left Pakatan with a difficult choice: remain in opposition for the foreseeable future, or make the necessary inroads by bringing elements of the BN into its midst. They opted, we argue, to make the Faustian bargain: the inclusion of UMNO-clone Bersatu allowed PH to win a majority of seats in the Peninsular Malay arena, while the de facto partnership with Warisan picked up vital seats in East Malaysia. The importance of BNsplinter parties in penetrating the former $\mathrm{BN}$ strongholds cannot be overstated, as they are directly responsible for half of the seats $\mathrm{PH}$ captured from the $\mathrm{BN}$ and likely indirectly responsible for a significant portion of the remainder. ${ }^{16}$ In short, the incorporation of BN splinter parties into the opposition coalition made it competitive in arenas where it had previously found little success, and without which it could not win enough seats to overthrow the world's longest ruling elected dominant party regime.

\section{Malaysia Baharu: Voting for change?}

What are the underlying voting patterns that brought about BN's defeat? Specifically, understanding what motivated voting behavior provides insights on the reform process and has relevance for situating Malaysia's transition into broader theories of democratization It is clear that Najib's personal unpopularity was a push factor contributing to anti-UMNO votes across at least the Peninsular Diverse, Peninsular Malay, and Northeast arenas. Similarly, many voters across the country voted against an economic model that had led to stagnated wages and increased living expenses. But even if a plurality of voters were unified in displeasure with UMNO's inner core and its governance failures, we argue that there were fundamental divergences in what voters were voting for: there was, in other words, no coherent and unified endorsement of a model to replace the $\mathrm{BN}$ governance across the four arenas.

The Peninsular Diverse arena is the clearest starting point to examine this divergence. Its diverse, largely urbanized, outward looking, and relatively educated population has long

\footnotetext{
${ }^{16}$ Warisan flipped six out of the ten previously BN-held parliamentary seats in Sabah. Similarly, Bersatu flipped twelve out of twenty-six previously BN-held parliamentary seats in the Peninsular Malay arena (i.e. 46\%). Though PKR flipped the same number of seats in this arena, this elides the indirect though almost certainly positive effect of Bersatu's membership in PH on the PKR's performance in this arena.
} 
been the source of (much of) Malaysia's progressive civil society and has consistently supported demands for political reform. Many of these demands align with those implied by modernization theory, including better governance, more space for civil society, and at least some liberalization of the social sphere. Within it, the DAP's - and to a lesser extend PKR's - long standing calls to reduce the prominence of state-imposed racial categorizations resonate strongly, as does the corresponding call to make opportunities in the public domain less conditional on racial and religious identities. This is reflected in the post-UMNO Malaysia Baharu vision that many of its voters hold: a Malaysia that is progressive, cosmopolitan, and (relatively) post-racial, in which all citizens enjoy an equal sense of belonging to the country, and the pronounced racial hierarchy of the NEP is at least somewhat levelled.

Identity politics play a strong role in the Northeast arena as well, though in a fundamentally different form. The prevailing contest was between two related visions of a Malay/Muslim-centric politics, as represented by UMNO and PAS. PAS's model, which advocates for a more orthodox form of Islamism and the formation of a juridical Islamic state (Ahmad Fauzi 2018), emerged triumphant. Shamsul AB attributes this in part to an increasingly prevalent "moralistic constituency" in the Northeast, which rejected PH due to its perceived anti-Islamic character and the $\mathrm{BN}$ due to its endemic corruption. ${ }^{17}$ It is noteworthy how poorly progressive alternatives to this model resonated among the electorate, as PAS and UMNO collectively captured over $90 \%$ of votes in the Northeast arena. This pattern has well-established roots: Hamayotsu (2013) argues that the exclusionary stances inherent to the model of orthodox Islam prevalent in the Northeast are a reaction to progressive demands in the peninsular urban cores, while Mohamed Osman (2017) notes that the "conservative turn" that underlies the results includes an explicit rejection of the Reformasi-inspired progressive agenda. In short, even with PAS splinter party Amanah contesting several seats, PH's perceived reform agenda was soundly rejected. Insofar as there was a vote for change in the Northeast, then, it was to increase the role of Islam in the state

\footnotetext{
${ }^{17}$ See “Siapa Lagi Melayu Mau” in The Star Online 9 June 2019.
} 
and to remove a scandal-plagued UMNO leadership, rather than to embrace a progressive model of Malaysia Baharu.

Identity politics played a prominent role in the Peninsular Malay arena as well. As in previous campaigns, UMNO positioned itself as the true defender of Malay rights, warning that its defeat would bring about an erosion of Malay privilege and Islamic primacy. That message brought resounding success in GE13, where UMNO won approximately $85 \%$ of the seats it contested. GE14's outcome was markedly different: UMNO won less than half the seats it contested, with PH winning all but three of the remainder.

How do we make sense of this dramatic shift? Bersatu's strategy in Peninsular Malay districts focused strongly on discrediting Najib and highlighting the failures of his administration. Largely absent, however, were strong references to the progressive elements of PH's reform agenda, let alone to any leveling of the racial hierarchy. Rahman (2018) convincingly argues that most rural Malay voters were largely ambivalent about PH, underscoring the notion that the vote shift within the Peninsular Malay arena can be read more as a rejection of Najib, rather than an endorsement of some fundamentally different alternative. In fact, Mahathir arguably offered conservative — and perhaps nostalgic_-Malay voters concerned with the erosion of Malay primacy a "return" to a more confident era of UMNO-led politics. In that sense, Mahathir and Bersatu offered voters an alternative UMNO model, one based on many of the same principle, but with different faces - "same same, but different". The embrace of that option is thus hardly an endorsement of the progressive and post-racial Malaysia Baharu espoused by counterparts in the Peninsular Diverse arena, and does not imply support for a leveling of the Malaysia's de facto racial hierarchy.

The distinct political dynamic of Sabah and Sarawak, where local elite networks and clientelistic practices are especially prominent, has received detailed scholarly attention (Faisal 2018; Chin 2014). In GE13, that dynamic allowed BN component parties to capture $86 \%$ of districts. PR, by contrast, secured only a few urban seats and PAS was totally ineffective. GE14 broke the BN's stranglehold on East Malaysia, with PH picking up over $40 \%$ of the seats it contested. As in the Peninsular Malay arena, many of PH's gains came through the cooptation of former BN-aligned elites. As such, the shift away from the BN appears less an endorsement of a new political model, and more a function of local elite 
realignment as well as other local factors that are distinct from the broader peninsular political discourse (Chin 2018; Mersat 2018).

What do the clear differences in voting behavior across the four arenas imply for theories of democratization? The progressive demands prevalent in the Peninsular Diverse arena align with modernization theory. Since PH secured 46 of the 112 seats needed for the transition from this arena, modernization theory clearly provides some analytic traction in explaining it. But it is not the whole story. In the other arenas, identity politics and elite splits are more compelling explanations. Beginning with the Northeast, a particular form of Islamist identity politics dominated, with the reformist aspects of PH's agenda being widely met with suspicion. There is no question that the rejection of Najib's governance failures was an important factor in the Peninsular Malay arena vote. That played out, however, against a backdrop of identity politics, where the elite-split that created the UMNO-clone Bersatu party allowed Mahathir to offer an alternative to UMNO which also credibly reassured conservative voters that Malay rights and the political primacy of the Malays would be preserved,. Mahathir lacked the Islamic credentials, however, to have a similar impact in the Northeast. Finally, the East Malaysia arena is driven by clientelism and political networks, with PH's inroads likewise following an elite split. Such divergent voting motivations preclude a single, coherent theory from explaining Malaysia's transition. Rather than force a single explanation on what are multiple, distinct phenomena, it may be more constructive to conceive of the election as several concurrent contests, each best understood by discrete explanations.

\section{Reform and Democratization in post-Transition Malaysia}

Perhaps the most important question facing Malaysia is whether ongoing reforms and democratization will produce results. We argue that the nature of political competition across the four arenas strongly has strong implications for PH's priorities and the bounds of what reforms it can feasibly pursue. Specifically, only one arena-Peninsular Malay-is both electorally pivotal and highly sensitive to the national political discourse. As a result, its impact on national level political calculations within the $\mathrm{PH}$ government is substantially amplified over the other arenas. We unpack and work through this logic below. 


\section{Strategic Considerations}

The comparatively progressive voters of the Peninsular Diverse arena have consistently supported PH's predecessors and will likely continue to support any coalition that contains PKR and the DAP in the short and medium term, as they have no credible alternative. They are, in short, a secure base for the coalition. ${ }^{18}$ Furthermore, PH's dominance of this arena means it has essentially no further seats to gain in it. In conjunction, this decreases the incentives PH's leadership has in responding to the arena's preferences.

In the Northeast arena, voters show little signs of shifting away from PAS in meaningful numbers, particularly as the moralistic constituency becomes more pronounced. The return of a grand coalition that brings PAS back into a partnership with progressive elements also appears highly unlikely for the foreseeable future, as the narrative of the DAP's anti-Islamic nature appears too deeply rooted to counter. Consequently, Kelantan and Terengganu are essentially unwinnable for $\mathrm{PH}$ or another similar coalitions, likewise deprioritizing that arena's preferences in national level political calculations as well.

That leaves the Peninsular Malay and East Malaysia arenas as the battlegrounds for inter-coalition political competition. While East Malaysia is electorally pivotal, it operates independently enough from the peninsula that a formula of non-interference in its personalistic politics and strategic concessions on local issues is often sufficient for the ruling coalition to count on support from the Bornean political elite, who bring voters with them. PH's incorporation of controversial former UMNO elite, particularly from Sabah, suggests strong continuity of this dynamic post-transition. In that respect, securing seats in East Malaysia has more to do with intra-elite bargaining and assurances of Bornean elite autonomy than it does with the national policy framework, rendering the arena's influence on national level policy calculations relatively muted as well.

That leaves the Peninsular Malay arena. With its large number of voters, whose political influence is amplified through extensive malapportionment, it is nearly impossible to retain power without a strong foothold in the arena. Yet PH's gains in GE14 were tenuous,

\footnotetext{
${ }^{18}$ Note the \#UndiRosak movement, in which progressive voters pledged to invalidate their ballots in protest against PH's perceived movement away from the progressive agenda prior to GE14 ultimately was a non-factor in the election.
} 
being based more on a rejection of now-sidelined Najib than an endorsement of PH's reform agenda. Moreover, UMNO retains a strong grassroots presence throughout the arena, compounding the risk that its pivotal voters could defect from $\mathrm{PH}$ and prevent the coalition from retaining power in GE15.

PH's attempts to consolidate power in the arena in the year after the election have been effectively countered by UMNO's strategy of doubling-down on the Malay agenda (Norshahril 2019). Specifically, UMNO has pushed a narrative that PH constitutes a threat to Malay primacy and will eventually lead to status loss for the Malays and Islam. The growing UMNO-PAS partnership compounds PH's difficulties in countering this message, as it is a major stride towards a Malay-unity political vehicle that can credibly assure Malay of their status. PH's loss to UMNO/PAS in three post-GE14 by-elections within this arena underscores the political precarity of the situation for the new government.

With Peninsular Malay votes both pivotal and vulnerable, components within the government that can secure votes there have found their influence strongly amplified. This is most evident in Mahathir's premiership, despite Bersatu having significantly fewer seats than either PKR or the DAP. As notable, Bersatu received approximately one cabinet position for every two of its parliamentary seats; the ratio for the multi-racial PKR and DAP, whose strongholds are in the Peninsular Diverse arena, was approximately one to seven. This has fundamentally shaped PH's political direction, with key statements - such as the following from PKR Deputy President Azmin Ali—sounding more UMNO than Reformasi-like: “[w]e must be brave and not hesitate in fulfilling our promises, especially on the Malay and Bumiputera agenda... We must do so without feeling apologetic or fearful of the criticisms of others" (Malaysiakini 2019).

\section{Identity Politics and Limits of Reform}

PH's general deference to the Peninsular Malay arena has produced a highly cautious approach to issues that affect Malaysia's implicit racial hierarchy. Consequently, large tracts of the Reformasi agenda too sensitive to directly address, disappointing the expectations of supporters from the Peninsular Diverse arena. Several examples illustrate the seemingly inescapable constraints of identity politics. In the months after the election, Mahathir 
announced that Malaysia would ratify the UN-backed International Convention for the Elimination of All Forms of Racial Discrimination (ICERD), which prohibits discrimination on the basis of "race, colour, descent, or national or ethnic origin." Numerous Malay rights groups, clearly endorsed by UMNO and PAS, seized upon the move, claiming that ICERD would undermine Malay and Muslim primacy (Waikar 2018). The movement's aggressive rhetoric and a significant anti-ICERD rally in December 2018 largely muted ICERD's supporters. PH relented, reversing its position, and leaving Malaysia as one of only seventeen countries_-including South Sudan, Myanmar, North Korean, and numerous small island states - that do not recognize the convention.

A similar dynamic is apparent in debates around the role of race in tertiary education admissions policies. Admission into the low-cost and accelerated pre-university matriculation program follows a quota under which $90 \%$ of spots are reserved for Malay and other Bumiputera applicants. This relegates non-Malays to costlier and longer-duration qualification channels. Many non-Malays view the system as discriminatory; it has also attracted criticism for undermining academic standards at Malaysia's public universities. PH campaigned in part on educational reform - including a pledge to increase equity in the tertiary education admissions process (Lee 2018) — but political pressure precipitated an early 2019 decision to maintain the 90/10 matriculation quota and increase the number of places in the program by $60 \%$, in effect further compounding the risk of non-Malays being crowded out of the public tertiary education.

Numerous other examples, including Malaysia's sudden withdrawal from the Rome Statute of the International Criminal Court and the furor resulting from Finance Minister Lim Guan Eng releasing a brief in Mandarin in addition to the customary Malay and English, speak to the sensitivities around any action that can be framed as challenging the position of the Malays at the top of the implicit racial hierarchy. As long as voters in the pivotal Peninsular Malay arena remain averse to an alternative social structure — and UMNO remains a viable political force that can leverage those anxieties - the politics of race and religion will continue to constrain the range of politically feasible reforms. 


\section{Democratization}

The constraints imposed by the Peninsular Malay arena's pivotal role have not, however, precluded meaningful progress in other areas of PH's agenda. Reports by IDEAS (2019) and Bersih (2019) highlight several of these. Notably, a series of constructive economic reforms have been carried out, including support for SMEs, anti-corruption measures, improvements to public procurement procedures, and greater transparency on fiscal positions.

Numerous institutional reforms are also notable. Significantly, the Electoral Commission (EC), which was essentially captured by the Prime Minister's Department (PMD) during late UMNO rule, has been moved under Parliamentary oversight. As the EC plays a central role in structuring the electoral process, its increased neutrality would substantially correct one of the major impediments to free and fair political competition in Malaysia. Other initiatives seek to reduce the concentration of power in the PMD, including reducing its number of ministers, ending the practice of the Prime Minister simultaneously holding the Minister of Finance portfolio, and significantly reducing the PMD's budget. As the concentration of power in the PMD was one of the major sources of governance failure under the BN (Ostwald 2017b), these reforms have the potential to support ongoing democratization.

Further measures seek to strengthen Parliament, for example through the introduction of a Parliamentary Select Committee system to support and check the Cabinet in key areas including Budget, Major Public Appointments, Defense and Home Affairs, and Federal State Relations. A working group to strengthen the largely symbolic upper house has also been formed. Concurrently, additional reforms have increased the space for a free press and an active civil society, both of which faced serious constraints under late BN governments. In a landmark decision, Parliament lowered the voting age to 18 and called for automatic registration of eligible voters, increasing the electorate from 14.9 million in GE14 to an estimated 22.7 million by the time GE15 is due in 2023. These are meaningful transformations of a political context that over sixty years was shaped to benefit UMNO and 
its coalition partners: if fully institutionalized, they unquestionably create greater space for political pluralism and competition. ${ }^{19}$

Ultimately, GE14 saw a dominant party concede defeat after over six decades in power. UMNO did not openly call for interference by state institutions, nor did it agitate for instability as was feared it might. A peaceful transition from such deeply entrenched rule is a historic achievement, particularly at a time of general democratic regression. It is indeed the case that the cooptation of $\mathrm{BN}$ elite was required to make the necessary electoral inroads, as was perhaps the premiership of Mahathir required to reassure anxious institutions. The need for such a Faustian bargain, though, is unsurprising: Malaysia's electoral process was designed, if not preserve UMNO rule, then at least to ensure that its core principles remain intact. While the dominance of the Peninsular Malay arena may strike some as undemocratic, it is worth remembering that such disproportionate influence is a core feature of some established democracies as well. The massively malapportioned United States Senate, for example, significantly inflates the influence of rural midwestern voters relative to their coastal and more urbanized counterparts. If such features are not seen as contradictory to the principles of democracy there, then the same should be true in the Malaysian context as well.

\footnotetext{
${ }^{19}$ At the time of writing, many of the discussed reforms have not be fully codified into law, leaving open the possibility of their reversal.
} 


\section{References}

Abdullah, Walid Jumblatt. 2019. "The Mahathir effect in Malaysia's 2018 election: the role of credible personaities in regime transitions", Democratization, 26(3): 521-536.

Ahmad Fauzi Abdul Hamid. 2018. "The Islamist Factor in Malaysia's 14th General Elections", The Round Table, 107(6): 683-701.

Bersih 2.0. 2019. First Year Report Card of Pakatan Harapan on Electoral, Political \& Institutional Reforms. BERSIH 2.0.

Bloomberg. "Najib warns Malay base of threat to Islam if opponents win power", 30 November, 2016.

Brownlee, Jason. 2007. Authoritarianism in an Age of Democratization. Cambridge: Cambridge University Press.

Case, William. 2017. "Stress testing leadership in Malaysia: The 1MDB scandal and Najib Tun Razak", The Pacific Review, 30(5): 633-654.

Chan Tsu Chong. 2018. "Democratic Breakthrough in Malaysia - Political Opportunities and the Role of Bersih", Journal of Current Southeast Asia Affairs, 3(1-2): 109-138.

Chin, James. 2018. "Sabah and Sarawak in the $14^{\text {th }}$ General Election 2018 (GE14): Local Factors and State Nationalism", Journal of Current Southeast Asia Affairs, 3(1-2): 173-192.

Chin, James. 2014. "Exporting the BN/UMNO Model: Politics in Sabah and Sarawak" in Meredith Weiss (ed), Routledge Handbook of Contemporary Malaysia, London and New York: Routledge, 83-92.

Chin, James. 2009. "The Malaysian Chinese Dilemma: The Never Ending Policy (NEP)", Chinese Southern Diaspora Studies, 3: 167-182.

Croissant, Aurel, and Philip Lorenz. 2018. Comparative Politics of Southeast Asia: An Introduction to Governments and Political Regimes. Heidelberg: Springer.

Dettman, Sebastian, and Meredith Weiss. 2018. "Has Patronage Lost Its Punch in Malaysia?", The Round Table, 107(6): 739-743.

Faisal S. Hazis. 2018. "Domination, Contestation, and Accommodation: 54 Years of Sabah and Sarawak in Malaysia", Southeast Asian Studies, 7(3): 341-361. 
Gandhi, Jennifer, and Elvin Ong. 2019. "Committed or Conditional Democrats? Opposition Dynamics in Electoral Autocracies", American Journal of Political Science, EarlyView.

Gomez, Edmund Terence. 2016. "Resisting the Fall: The Singapore Dominant Party, Policies and Elections in Malaysia" Journal of Contemporary Asia, 46(4): 570-590.

Gomez, Edmund Terence. 2012. "Monetizing Politics: Financing Parties and Elections in Malaysia”, Modern Asian Studies, 46(5): 1370-1397.

Gomez, Edmund Terence and Mohamed Nawab Mohamed Osman (eds). 2019. Malaysia's 14th General Election and UMNO's Fall: Intra-Elite Feuding in the Pursuit of Power. Routledge.

Gomez, Edmund Terence, and Johan Saravanamuttu (eds). 2012. The New Economic Policy in Malaysia: Affirmative Action, Ethnic Inequalities and Social Justice. Singapore: NUS Press.

Hamayotsu, Kikue. 2013. "Towards a More Democratic Regime and Society? The Politics of Faith and Ethnicity in a Transitional Multi-Ethnic Malaysia", Journal of Current Southeast Asian Affairs, 32(2): 61-88.

Haggard, Stephan, and Robert Kaufman. 2016. "Democratization During the Third Wave", Annual Review of Political Science, 19: 125-144.

Horowitz, Donald. 1993. "The Challenge of Ethnic Conflict: Democracy in Divided Societies", Journal of Democracy, 4(4): 18-38.

Horowitz, Donald. 1985. Ethnic Groups in Conflict. Berkeley: University of California Press.

Hutchinson, Francis. 2018. "Malaysia's $14^{\text {th }}$ General Elections: Drivers and Agents of Change", Asian Affairs, 49(4): 582-605.

IDEAS. 2019. Projek Pantau: Report Card No. 2, prepared by Faiz Zaidi, Aira Azhari, and Laurence Todd. Institute for Democracy and Economic Affairs.

Kessler, Clive. 1978, Islam and Politics in a Malay State: Kelantan 1839-1969. Ithaca: Cornell University Press.

Lee Hwok-Aun. 2018. "Education in Post GE-14 Malaysia: Promises, Overtures and Reforms". ISEAS Perspective, no. 59.

Lemiere, Sophie (ed). 2019. Minorities Matter: Malaysian Politics and People (Vol. III). Kuala Lumpur: SIRD \& Singapore: ISEAS-Yusof Ishak Institute. 
Lemiere, Sophie. 2018. “The Downfall of Malaysia's Ruling Party", Journal of Democracy, 29(4): 114-128.

Nadzri, Mohamad. 2018. "The 14th General Election, the Fall of Barisan Nasional, and Political Development in Malaysia, 1957-2018", Journal of Current Southeast Asian Affairs, 37(3): 139-171.

Oliver, Steven, and Kai Ostwald. 2018. "Not Enough to Win Another Lost Election: Malapportionment and Partisan Bias in Malaysia" Working paper available at ResearchGate.

Ostwald, Kai. 2013. "How to Win a Lost Election: Malapportionment and Malaysia's 2013 General Election", The Round Table, 102(6): 521-532.

Ostwald, Kai. 2017a. "Malaysia's Electoral Process: The Methods and Costs of Perpetuating UMNO Rule" ISEAS Trends in Southeast Asia, no. 19.

Ostwald, Kai. 2017b. "Federalism without Decentralization: Power Consolidation in Malaysia", Journal of Southeast Asian Economies, 34(3): 488-506.

Ostwald, Kai, Paul Schuler, Jie Ming Chong. 2018. "Triple Duel: The Impact of Coalition Fragmentation and Three-Corner Fights on the 2018 Malaysian Election", Journal of Current Southeast Asian Affairs, 3(1-2): 31-56.

Malaysiakini. 2019. “After Semenyih loss, Azmin wants bumi agenda fulfilled without apology” Published online 3 March 2019.

Mersat, Neilson Ilan. 2018. “The Sarawak Dayaks' Shift in Malaysia's 2018 Election”, The Round Table, 107(6): 729-737.

Mohamed Osman, Mohamed Nawab. 2017. "The Islamic Conservative Turn in Malaysia: Impact and Future Trajectories", Contemporary Islam, 11(1): 10-20.

Ng, Jason, Gary Rangel, Santha Vaithilngam, and Subramaniam Pillay. 2015. "The 2013 Malaysian Elections: Ethnic Politics or Urban Wave?", Journal of East Asian Studies, 15(2): 167-198.

Noor, Farish A. 1999. "Looking for reformasi: The discursive dynamics of the reformasi movement and its prospects as a political project", Indonesia and the Malay World, 27(77): 5-18.

Norshahril Saat. 2019. "A Complicated Political Reality Awaits the Malays", ISEAS Perspective, no. 40. 
Pakatan Harapan. 2018. Buku Harapan: Rebuilding our Nation Fulfilling our Hopes. Available online at:

http://kempen.s3.amazonaws.com/manifesto/Manifesto_text/Manifesto_PH_EN.pdf

Pepinsky, Thomas. 2015. "Interpreting Ethnicity and Urbanization in Malaysia's 2013 General Election", Journal of East Asian Studies, 15(2): 136-163.

Pepinsky, Thomas. 2007. "Autocracy, elections, and fiscal policy: evidence from Malaysia”, Studies in Comparative International Development, 42(1-2): 136-163.

Puthucheary, Mavis. 2008. "Malaysia's 'social contract': The invention and historical evolution of an idea" in Norani Othman, Mavis Putucheary and Clive Kessler (eds), Sharing the nation: Faith, difference, power and the state 50 years after Merdeka. Kuala Lumpur: SIRD.

Rahman, Serina. 2018. "Was It a Malay Tsunami? Deconstructing the Malay Vote in Malaysia's 2018 Election”, The Round Table, 107(6): 669-682.

Saravanamuttu, Johan, and Maznah Mohamad. 2019. "The Monetisation of Consent and its Limits: Explaining Political Dominance and Decline in Malaysia", Journal of Contemporary Asia, FirstView.

Shamsul A.B. and Athi S.M. 2014. "Ethnicity and identity formation: Colonial knowledge, colonial structures and transition" in Meredith Weiss (ed), Routledge Handbook of Contemporary Malaysia, London and New York: Routledge, 267-278.

Slater, Dan. 2018. "Malaysia’s modernization tsunami” East Asia Forum.

Slater, Dan. 2012. "Strong-state democratization in Malaysia and Singapore", Journal of Democracy, 23(2): 19-33.

Thompson, Eric. 2013. "Urban Cosmopolitan Chauvinism and the Politics of Rural Identity" in Tim Bunnell, D. Parthasarthy, and Eric Thompson (eds) Cleavage, Connection and Conflict in Rural, Urban and Contemporary Asia. Dordrecht: Springer.

Waikar, Prashant. 2018. "ICERD and Old Politics: New Twists in Post-Election Malaysia?", RSIS Commentaries, no. 2014.

Weiss, Meredith. 2006. Protests and possibilities: Civil society and coalitions for political change in Malaysia. Stanford: Stanford University Press.

Welsh, Bridget. 2018. “'Saviour' Politics and Malaysia’s 2018 Electoral Democratic Breakthrough: Rethinking Explanatory Narratives and Implications", Journal of Current Southeast Asian Affairs, 3(1-2): 85-108. 
Wong Chin Huat. 2018. "Constituency Delimitation and Electoral Authoritarianism in Malaysia", The Round Table, 107(1): 67-80.

Wong Chin Huat and Ooi Kee Beng. 2018. "Introduction: How Did Malaysia End UMNO's 61 Years of One-Party Rule? What's Next?", The Round Table, 107(6): 661-667.

Wong Chin Huat, James Chin, and Norani Othman. 2010. "Malaysia - towards a topology of an electoral one-party state", Democratization, 17(5): 920-949. 